\title{
Implementasi Model Cooperative Learning Metode TGT Melalui Media Audiovisual Dalam Pembelajaran Aktivitas Ritmik Lompat Tali Di Sekolah Dasar
}

\author{
Siti Saskia $^{1}$, Agus Mahendra ${ }^{1}$, Neneng Samini ${ }^{2}$ \\ ${ }^{1}$ Program Studi Pendidikan Guru Sekolah Dasar Pendidikan Jasmani, Universitas Pendidikan Indonesia \\ ${ }^{2}$ SDN 044 CICADAS Awigombong, Bandung
}

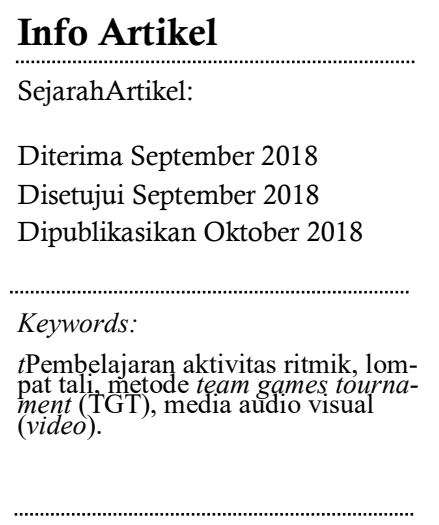

\begin{abstract}
Abstrak
Penelitian ini bermaksud melihat efektivitas pembelajaran lompat tali sabagi bagian dari aktivitas ritmik dengan menggunakan model kooperatif berformat TGT. Subjek penelitian adalah peserta siswa kelas IV SDN 044 Cicadas Awigombong, berjumlah 25 orang. Penelitian ini dilaksanakan dengan pendekatan Penelitian Tindakan Kelas, dengan mengelaborasi dua siklus, yang masing-masing terdiri dari dua tindakan, menggabungkan penggunaan model kooperatif dengan media audiovisual, dan kemajuannya diukur melalui tes lompat tali dan lembar pengamatan terstruktur. Data terkumpul dianalisis dan diolah dengan persentase sehingga dapat disimpulkan bahwa hasil observasi awal terhadap nilai kerjasama sebesar $20 \%$, yang meningkat menjadi $89 \%$. Demikian juga dalam hal keterampian lompat tali, yang hasil observasi awal sebesar 38\%, meningkat menjadi 95\%. Kesimpulannya, implementasi model pembelajaran kooperatif metode TGT dengan bantuan media audio visual (video) memberikan pengaruh yang signifikan terhadap peningkatan keterampilan lompat tali dan kerjasama siswa kelas IV di SD Negeri 044 Cicadas Awigombong.
\end{abstract}

\begin{abstract}
This research's aim is to improve the learning effectiveness of skipping rope as part of rhythmical activities with employing cooperative learning in TGT format. The participant of this research is Forth Grader of SDN 044 of Cicadas Awigombong, totalling 25 pupils. The study was conducted by Classroom Action Research format, elaborating two cycles, each of which consist of two actions, mingling cooperative model and audio-visual media, and its progress was measured by means of skipping rope skill test and semi-structured observational sheet. The collected data were analysed by percentage format so that the result can be summarized. The progress of skipping rope skill from initial observation to the last test were from $20 \%$ to $89 \%$, while the progress of cooperative skill from initial observation to the last action were from $38 \%$ to 95\%. It can be concluded that the implementation of cooperative learning model (TGT format) combined with audio-visual media is effective in improving both the skipping rope and cooperative skill of the children of the 4th grade students of SDN 044 Cicadas Awigombong
\end{abstract}




\section{PENDAHULUAN}

Penelitian ini didorong oleh masih banyaknya persoalan yang masih membelit program Pendidikan Jasmani, Olahraga dan Kesehatan di sekolah. Persoalan-persoalan tersebut menggejala dalam banyak hal, dimulai dari terbatasnya peralatan dan tempat berlangsungnya pembelajaran Penjas, hingga persoalan ketepatan materi belajar yang harus dikuasai siswa SD yang bersumber dari masih berbedabedanya guru penjas dalam menginterpretasikan isi silabus dan Kompetensi Dasar (KD) dalam Kurikulum 2013.

Dalam hal materi ajar, misalnya, hingga saat ini masih terdapat perbedaan dalam hal konten apa yang harus ada dalam ruang lingkup pembelajaran aktivitas ritmik. Sebagian guru menerjemahkan bahwa materi aktivitas ritmik identik dengan senam ritmik, atau ada juga yang menganggap bahwa ia melulu berisi senam aerobik. Padahal ruang lingkup aktivitas ritmik amat meluas, termasuk di dalamnya lompat tali (skipping rope) yang mengandung banyak manfaat, baik dari sisi koordinasi maupun dari sisi kebugaran jasmani (Mahendra, 2015a).

Di pihak lain, persoalan klasik pun masih jelas menggejala dalam hal pemahaman dan penguasaan guru terhadap model-model pembelajaran, pendekatan, serta gaya mengajar yang seharusnya digunakan guru dalam mengajar Penjas di SD. Salah satu gejalanya adalah mayoritas guru Penjas masih mengajar dengan model atau pendekatan langsung (direct teaching), sehingga semua perilaku mengajarnya masih selalu berorientasi kepada penguasaan keterampilan gerak dari siswa. Padahal sudah banyak diungkap oleh para ahli bahwa arah dari pembelajaran Penjas haruslah mencakup perubahan pada semua aspek pembelajaran, yaitu dalam domain kognitif, domain afektif, dan domain psikomotor (Mahendra, 2015b).

Permasalahan yang diungkap di atas sangat jelas terasa dan langsung dialami penulis ketika penulis menjadi guru pengganti di SD Negeri 044 Cicadas Awigombong. Masalah guru yang dapat teridentifikasi dalam pembelajaran adalah masih tidak dikenalnya modelmodel pembelajaran oleh guru, sehingga pembelajaran berlangsung seolah satu arah, karena sebagai konsekuensinya guru pun selalu bersandar pada gaya mengajar tunggal yaitu gaya komando. Demikian juga dalam hal konten materi ajar, di mana guru sangat tidak mengenal hakikat pembelajaran aktivitas ritmik, sehingga siswa tidak mengenal berbagai keterampilan gerak dasar yang ada dalam wilayah aktivitas tersebut, seperti pola langkah, pantulan bola, tepukan, bahkan hingga lompat tali dan tarian.

Dengan demikian, di samping siswa kurang mendapatkan pengalaman gerak yang kaya dan berharga, siswa pun amat kurang keterlibatannya dalam aspek-aspek di luar psikomotor ketika mengikuti pembelajaran Penjas. Jika hal tersebut dibiarkan, maka dapat diduga dengan mudah bahwa siswa akan banyak dirugikan, dan karenanya perlu ada suatu upaya untuk mengubah kondisi yang ada. Salah satu upaya tersebut adalah dalam hal bagaimana model pembelajaran dapat diperkenalkan kepada guru dan bagaimana konten materi ajar juga diperkenalkan kepada siswa.

Atas dasar pemikiran itulah, penulis membuat rencana tindakan untuk melaksanakan program perbaikan dalam bentuk Penelitian Tindakan Kelas dengan: Implementasi Model Kooperatif format TGT Melalui Media AudioVisual pada Pembelajaran Aktivitas Ritmik 
Lompat Tali pada Siswa Kelas IV SDN 044 Cicadas Awigombong. Penelitian ini akan dilaksanakan bersama (kolaboratif) dengan guru Penjas, sehingga tindakan ini bukan saja membantu siswa terlibat dalam pembelajaran yang bersifat holistic, tetapi juga sekaligus mengajak guru untuk menguasai penerapan model kooperatif yang digabungkan dengan penggunaan media audio-visual.

Sebagaimana diketahui, model pembelajaran kooperatif (cooperative learning) dapat diterapkan pada proses pembelajaran sebagai solusi terhadap masalah yang telah dikemukakan sebelumnya. Karena pembelajaran kooperatif merupakan strategi belajar dimana peserta didik belajar dalam kelompok kecil dengan keahlian berbeda, dan di dalam kelompok kecil tersebut peserta didik saling belajar dan bekerja sama untuk sampai pada pengalaman belajar yang optimal baik pengalaman individu maupun pengalaman kelompok.

Format pembelajaran Teams Games Tournament (TGT) merupakan salah satu format kerja pembelajaran beregu dengan menggunakan pendekatan kooperatif, di mana para peserta didik dikelompokkan 4-6 orang secara heterogen berdasarkan jenis kelamin, agama, dan etnis sehingga dapat melatih kecakapan sosial setiap individu. Dalam lingkup kelompok, mereka akan saling bekerjasama, berdiskusi dan tolong menolong dalam mengerjakan tugas kelompok serta berkolaborasi mendukung tujuan kelompok untuk unggul dari kelompok lain. Setiap individu dalam kelompok tersebut memberikan kontribusi untuk pencapaian skor kelompoknya masingmasing.

Format TGT dalam pembelajaran kooperatif menuntut agar siswa dari semua ke- lompok mempelajari hal yang sama, dan di antara kelompok mereka harus berusaha untuk berkompetisi dengan kelompok lain. Atas dasar tuntutan tersebut, setiap anggota dari suatu kelompok harus bekerjasama saling mendukung, agar dapat mengangkat kepentingan kelompok. Dalam kegiatan pembelajaran ketika menggunakan metode TGT ini semua peserta didik memiliki peluang yang sama untuk memperoleh prestasi, baik sebagai individu maupun sebagai anggota kelompok.

Materi ajar yang dipilih peneliti untuk meningkatkan hasil belajar adalah aktivitas ritmik. Aktivitas ritmik dalam pendidikan jasmani dapat dijadikan alat untuk mengembangkan orientasi gerak tubuh sehingga anak-anak memiliki unsur-unsur kemampuan tubuh yang multilateral (Mahendra, 2017). Materi ajar dalam aktivitas ritmik yang digunakan dalam penelitian ini adalah permainan lompat tali. Permainan lompat tali termasuk materi ajar yang sangat jarang diberikan kepada peserta didik Selain itu, lompat adalah salah satu gerak dasar yang mampu mengembangkan literasi fisik anak. Lompat merupakan gerak dasar yang mampu menunjang anak untuk mengembangkan biomotor seperti kekuatan dan kecepatan serta power saat mereka tumbuh. Dengan gerakan yang sederhana dan mudah diikuti, lompat dapat menjadi tujuan mengekspresikan gerak yang diaplikasikan kedalam permainan lompat tali.

Di sisi lain, perkembangan teknologi sekarang ini sangatlah pesat. Salah satu produk teknologi yang dapat memberikan kemudahan dalam menyampaikan materi pembelajaran pendidikan jasmani adalah media audio visual. Dengan menggunakan media audio visual yang menyajikan gambar bergerak dikombinasikan 
dengan latar suara yang menjadi keunggulan media audio visual dibandingkan dengan media pembelajaran lain, akan memudahkan guru dalam menyampaikan materi aktivitas ritmik yang membutuhkan latar suara sebagai pedoman ritme gerakan dan gambar bergerak sebagai pedoman rangkaian gerak kepada peserta didik. Selain itu, penyampaian materi dapat diputar ulang ketika peserta didik mengalami kesulitan. Penggunaan media audio visual ini juga dapat menarik minat peserta didik dalam proses pembelajaran, karena penggunaannya tergolong masih jarang. Dengan demikian, guru dapat mengembangkan kemampuan kognitif, afektif, dan psikomotor yang lebih baik dari siswa, dengan harapan akan mendapatkan hasil pembelajaran yang lebih maksimal

\section{METODE PENELITIAN}

\section{Jenis Penelitian}

Jenis penelitian yang digunakan penulis dalam penelitian ini adalah penelitian tindakan kelas (classroom action research). Penelitian tindakan kelas, dipilih sesuai dengan masalah yang dihadapi oleh peneliti sendiri. Penelitian tindakan kelas merupakan suatu pencermatan terhadap kegiatan belajar berupa tindakan, yang sengaja dimunculkan dan terjadi dalam sebuah kelas secara bersama (Arikunto, 2013). Jenis dan rancangan penelitian yang digunakan dalam penelitian ini merujuk pada rancangan model Kurt Lewin yang terdiri atas 4 komponen, yaitu : 1) perencanaan atau planning, 2) tindakan atau acting, 3) pengamatan atau observing, 4) refleksi atau reflecting. (Subroto dkk 2017).

\section{Populasi}

Subjek penelitian ini adalah peserta didik kelas IV Sekolah Dasar Negeri 044 Cicadas
Awigombong, Jl. Asep Berlian No. 33 Bandung, dengan jumlah 25 peserta didik dengan perincian 17 putri dan 8 putra.

\section{Instrumen Penilaian}

Alat ukur dalam penelitian biasanya dinamakan instrumen penelitian (Sugiyono, 2015). Instrumen penelitian merupakan alat yang digunakan untuk mengukur fenomena alam maupun sosial yang akan diamati atau di teliti. Adapun instrument dalam penelitian ini adalah lembar observasi dan tes keterampilan lompat tali.

\section{Lembar Observasi}

Observasi dilakukan berdasarkan penglihatan kepada apa yang terjadi di lapangan sesuai dengan aktivitas peserta didik saat proses pembelajaran. Dari segi proses pelaksanaan pengumpulan data, observasi yang dilakukan merupakan observasi nonpartisipan.

Penelitian yang dilakukan yaitu untuk mengukur nilai kerjasama peserta didik dalam pembelajaran aktivitas ritmik lompat tali dengan menggunakan model pembelajaran kooperatif metode TGT. Kisi-kisi nilai kerjasama didapatkan dari penilaian antarindividu akibat dari situasi yang kooperatif berdasarkan perilaku-perilaku belajar kelompok menurut Deutsch (1949) antara lain: diskusi (discussion), orientasi (orientation), kebersamaan (centredness), keterlibatan (involvement), komunikasi (communication), dan perhatian (attention), serta sikap penerimaan (acceptance), dan penolakan (rejection) (dalam Huda, 2012). 
Tabel 1. Kisi-kisi Instrumen Nilai Kerjasama

\begin{tabular}{|c|c|c|c|}
\hline \multirow[t]{8}{*}{$\begin{array}{l}\text { Perilaku- } \\
\text { perilaku bela- } \\
\text { jar kelompok } \\
\text { menurut } \\
\text { Deutsch } 1949 \\
\text { (dalam Huda, } \\
\text { 2012). }\end{array}$} & $\begin{array}{l}\text { Diskusi } \\
\text { (discuss } \\
\text { ion). }\end{array}$ & 1 & $\begin{array}{l}\text { Saling mengajari } \\
\text { dan berbagi infor- } \\
\text { masi dengan teman } \\
\text { untuk mempelajari } \\
\text { tugas gerak. } \\
\text { Mengajak teman } \\
\text { untuk belajar bersa- } \\
\text { ma-sama. }\end{array}$ \\
\hline & $\begin{array}{l}\text { Keber- } \\
\text { samaan } \\
\text { (centre } \\
\text { dness) }\end{array}$ & 1 & $\begin{array}{l}\text { Tidak memilih te- } \\
\text { man dalam belajar } \\
\text { dan bermain. } \\
\text { Memperlakukan } \\
\text { teman dengan adil. }\end{array}$ \\
\hline & $\begin{array}{l}\text { Per- } \\
\text { hatian } \\
\text { (attenti } \\
\text { on). }\end{array}$ & 1 & $\begin{array}{l}\text { Menyemangati } \\
\text { teman untuk belajar. } \\
\text { Mendorong teman } \\
\text { agar } \\
\text { melakukan } r \text { tugas } \\
\text { gerak. }\end{array}$ \\
\hline & $\begin{array}{l}\text { Keterli- } \\
\text { batan } \\
\text { (involve } \\
\text { ment). }\end{array}$ & 1 & $\begin{array}{l}\text { Belajar bersungguh- } \\
\text { sungguh dengan } \\
\text { teman. }\end{array}$ \\
\hline & $\begin{array}{l}\text { Sikap } \\
\text { pen- } \\
\text { erimaan } \\
\text { (accept } \\
\text { ance). }\end{array}$ & 1 & $\begin{array}{l}\text { Menghargai kemam- } \\
\text { puan masing- } \\
\text { masing. } \\
\text { Dapat menerima } \\
\text { kritik dan masukan } \\
\text { teman. }\end{array}$ \\
\hline & $\begin{array}{l}\text { Sikap } \\
\text { pe- } \\
\text { nolakan } \\
\text { (rejecti } \\
\text { on). }\end{array}$ & 1 & $\begin{array}{l}\text { Bermain dilakukan } \\
\text { dengan gembira. } \\
\text { Tidak mudah ter- } \\
\text { singgung. }\end{array}$ \\
\hline & $\begin{array}{l}\text { Komu- } \\
\text { nikasi } \\
\text { (commu } \\
\text { nicatio } \\
n) \text {. }\end{array}$ & 1 & $\begin{array}{l}\text { Saling menjaga } \\
\text { ucapan dan perla- } \\
\text { kuan kepada teman. } \\
\text { Saling mendenga } \\
\text { kan dan mempertim- } \\
\text { bangkan saran te- } \\
\text { man. }\end{array}$ \\
\hline & $\begin{array}{l}\text { Orien- } \\
\text { tasi } \\
\text { (orienta } \\
\text { tion). }\end{array}$ & 1 & $\begin{array}{l}\text { Melaksanakan tugas } \\
\text { sesuai intruksi yang } \\
\text { diberikan. }\end{array}$ \\
\hline
\end{tabular}

Deutsch 1949 (Huda, 2012).

\section{Tes Keterampilan}

Salah satu instrumen yang sering digunakan dalam evaluasi proses pembelajaran di sekolah adalah tes. Tes keterampilan ini dilakukan untuk melihat kemampuan peserta didik terhadap keterampilan lompat tali. Penilaian dilakukan berdasarkan gerak yang dihasilkan oleh peserta didik sesuai dengan kriteria yang telah ditentukan, serta pada banyaknya lompatan yang berhasil dikumpulkan pada keterampilan lompat tali tahap 1 dan 2 disetiap pertemuan, yang kemudian skor yang diperoleh setiap individu anak dijumlahkan dari setiap lompatan yang dihasilkan untuk menentukan rangking dari jumlah skor seluruh kelompok belajar.
Tabel 2. Format Penilaian Kelompok Tes Keterampilan Lompat Tali

\begin{tabular}{|c|c|c|c|c|c|c|}
\hline \multirow[b]{2}{*}{$\mathrm{NO}$} & \multirow{2}{*}{$\begin{array}{l}\text { Nama } \\
\text { Anggota } \\
\text { Kelompok }\end{array}$} & \multicolumn{3}{|c|}{$\begin{array}{l}\text { Kriteria } \\
\text { Keterampilan } \\
\text { Lompat Tali } \\
\end{array}$} & \multirow[b]{2}{*}{ Total Skor } & \multirow[b]{2}{*}{ Frekuensi } \\
\hline & & 1 & 2 & 3 & & \\
\hline \multicolumn{7}{|l|}{1} \\
\hline \multicolumn{7}{|l|}{2} \\
\hline \multicolumn{7}{|l|}{3} \\
\hline \multicolumn{7}{|l|}{4} \\
\hline \multicolumn{7}{|l|}{5} \\
\hline \multicolumn{7}{|c|}{ Jumlah Keseluruhan } \\
\hline Rang & ing & & & & & \\
\hline
\end{tabular}

\section{Catatan Lapangan}

Catatan lapangan merupakan tulisan mengenai apa yang terjadi di lapangan, tentang apa yang dilihat, didengar, dialami, dan dipikirkan oleh peneliti ketika berada di lapangan. Catatan lapangan ini dibuat oleh peneliti yang melakukan pengamatan mengenai subjek dan objek penelitian. Hal-hal yang perlu dicatat antara lain kejadian yang terjadi pada saat proses pembelajaran berlangsung.

\section{Analisis Data}

Analisis data merupakan suatu upaya mengolah data menjadi informasi yang dilakukan dengan suatu kegiatan dengan cara diteliti, dipelajari dan memeriksa serta membandingkan data dan membuat data interpretasi yang diperlukan dalam penelitian. Teknik analisis data akan dilakukan dengan menggunakan teknik analisis data kuantitatif deskriptif, data kuantitatif yang berwujud dari hasil penguasaan peserta didik dianalisis secara deskriptif dengan menggunakan statistika deskriptif. Dalam pengolahan dan kategorisasi data terdiri dari beberapa langkah diantaranya sebagai berikut: 


\section{Mencari nilai rata-rata $(\mathrm{X})$}

$\mathrm{X}=$

Keterangan :

$$
\begin{array}{llll}
\mathrm{X} & =\sum x_{\tilde{i}} & \text { Nilai rata-rata } \\
\mathrm{Xi} & = & \text { Skor yang didapat } \\
\mathrm{n} & = & \text { Banyaknya data } \\
\Sigma & =\text { Menyatakan jumlah }
\end{array}
$$

Sumber: Darajat dan Abduljabar (2014).

\section{Mencari nilai praktek keterampilan lompat tali}

Pengolahan data untuk mengukur hasil belajar peserta didik dilakukan secara kuantitatif langsung melalui penskoran terhadap hasil tes peserta didik. Adapun cara mengolah hasil nilai praktek keterampilan permainan lompat tali yang memiliki 3 unsur praktek adalah sebagai berikut :

$$
=\frac{\mathrm{NP} 1+\mathrm{NP} 2+\mathrm{NP} 3}{3}
$$

$(\mathrm{NAP})=\frac{\text { jumlah keseluruhantotal skor peserta didil }}{\text { jumlah total peserta didikX skor maksimal }} \times 100 \%$

Sumber: Mahendra (2015).

Tingkat keberhasilan yang dicapai dibagi menjadi 5 kategori, yaitu:

\begin{tabular}{|l|l|}
\hline $\begin{array}{l}\text { Prestase Keberhasi- } \\
\text { lan }\end{array}$ & $\begin{array}{l}\text { Kategori Prestasi } \\
\text { Belajar }\end{array}$ \\
\hline $90 \%-100 \%$ & Baik Sekali \\
\hline $80 \%-90 \%$ & Baik \\
\hline $70 \%-80 \%$ & Sedang \\
\hline$-70 \%$ & Kurang \\
\hline
\end{tabular}

Sumber: Mahendra (2015).

\section{HASIL PENELITIAN}

Dari pelaksanaan tindakan-tindakan yang telah dilakukan oleh peneliti dalam proses pem- belajaran aktivitas ritmik lompat tali dengan menerapkan model pembelajaran kooperative metode TGT serta melalui media audio visual, maka hasil yang dapat dicapai oleh guru maupun peserta didik antara lain:

\section{Meningkatkan nilai kerjasama peserta didik}

Dengan menggunakan model pembelajaran kooperatif metode TGT dalam pembelajaran aktivitas ritmik lompat tali, selain dapat berpengaruh positif terhadap aspek jasmani peserta didik, juga dapat berpengaruh terhadap meningkatnya nilai-nilai kerjasama yang dibangun oleh masing-masing individu di dalam sebuah kelompok. Melalui proses belajar yang dilakukan secara berkelompok, peserta didik belajar membiasakan diri untuk dapat belajar secara demokratis serta berpartisipasi dalam setiap prosesnya untuk saling membantu serta mengembangkan nilai-nilai kerjasama, baik di dalam proses pembelajaran pendidikan jasmani maupun di dalam kehidupan sehari-hari.

\section{Membantu meningkatkan keterampilan lom- pat tali peserta didik}

PTK dalam pembelajaran aktivitas ritmik lompat tali dengan menerapkan model pembelajaran kooperatif metode TGT melalui media audio visual, mampu membantu memudahkan peserta didik dalam mempelajari serta melatih ketajaman koordinasi juga keluwesan tubuh untuk meningkatkan keterampilan lompat tali yang dimilikinya. Selain itu, unsur kompetitif di dalam proses pembelajaran aktivitas ritmik lompat tali akan mendorong peserta didik untuk dapat bersaing secara sportif dengan kelompok lain serta membuat masing-masing individu dalam kelompok saling memotivasi satu sama lain agar mencapai hasil belajar yang optimal. 
Melalui bantuan media audio visual peserta didik dibantu dengan lebih mudah dalam mempelajari materi ajar aktivitas ritmik lompat tali yang membutuhkan latar suara serta gambar bergerak sebagai pedoman ritme dalam melakukan keterampilan lompat tali, sehingga mengurangi kesulitan peserta didik dalam mendapat informasi mengenai rangkaian gerak yang dibutuhkan dalam melakukan keterampilan lompat tali.

\section{KESIMPULAN}

Model pembelajaran kooperatif metode team games tournament (TGT) dalam pembelajaran aktivitas ritmik lompat tali melalui media audio visual (video) bagi peserta didik kelas IV SD Negeri 044 Cicadas Awigombong menunjukkan peningkatan hasil pembelajaran yang signifikan di setiap pelaksanaan tindakan. Maka kesimpulan dari penelitian ini, yang pertama adalah bahwa penerapan model pembelajaran kooperatif metode team games tournament (TGT) dalam pembelajaran aktivitas ritmik lompat tali melalui media audio visual (video) mampu mengembangkan nilai kerjasama peserta didik dengan presentase pada tahap observasi awal sebesar 20\% meningkat menjadi $89 \%$. Yang kedua penerapan model pembelajaran kooperatif metode team games tournament (TGT) dalam pembelajaran aktivitas ritmik lompat tali melalui media audio visual (video) mampu meningkatkan keterampilan lompat tali peserta didik dengan presentase pada tahap pretest sebesar 38\% meningkat menjadi 95\%. Dan yang terakhir, peningkatan hasil belajar yang lebih besar dengan menerapkan model pembelajaran kooperatif metode team games tournament (TGT) dalam pembelajaran aktivitas ritmik lompat tali melalui media audio visual (video) yaitu pada keterampilan lompat tali dengan jumlah presentase $95 \%$.

Hasil tersebut di atas menunjukkan adanya efektivitas pembelajaran yang dilakukan dengan menerapkan model pembelajaran kooperatif metode TGT melalui media audio visual dalam pembelajaran aktivitas ritmik lompat tali, sehingga terdapat perubahan sikap peserta didik dalam mengikuti proses pembelajaran serta mengalami peningkatan hasil belajar terhadap keterampilan lompat tali peserta didik.

Maka dari itu berdasarkan analisis data hasil penelitian yang penulis lakukan, terbukti bahwa dengan menerapkan model cooperative learning metode TGT melalui media audio visual dalam pembelajaran aktivitas ritmik lompat tali berhasil meningkatkan hasil belajar terhadap keterampilan lompat tali serta nilai kerjasama peserta didik kelas IV di SD Negeri 044 Cicadas Awigombong. 


\section{DAFTAR PUSTAKA}

Arikunto, S. (2013). Prosedur Penelitian Suatu Pendekatan Praktik. Jakarta: PT. Rinekan Cipta.

Darajat, J \& Bambang, A. (2014). Aplikasi Statistika dalam PENJAS. Bandung: FPOK UPI.

Huda, M. (2012). Cooperative Learning Metode, Teknik, Struktur dan Model Penerapan. Yogyakarta: Pustaka Pelajar.

Mahendra, A. (2015a). Pembelajaran Musik dan Gerak: Dasar Pengembangan Aktivitas Ritmik di Sekolah Dasar.. Bandung: CV. Bintang WarliArtika

Mahendra, A. (2015b). Filsafat Pendidikan Jasmani: Dasar-Dasar Pembelajaran Penjas di Sekolah Dasar. Bandung: CV Bintang WarliArtika.

Mahendra, A. (2017). Model Pendidikan Gerak: Implementasi Pendidikan Jasmani Di Sekolah Dasar. Bandung: FPOK UPI

Subroto, T., Yunyun, Y., Yusuf, H. (2017). Buku Pedoman Penulisan Penelitian Tindakan Kelas dalam Pendidikan Jasmani, Olahraga, dan Kesehatan. Bandung: FPOK UPI.

Sugiyono. (2015). Metode Penelitian Pendidikan Pendekatan Kuantitatif, Kualitatif, dan R\&D. Bandung: Alfabeta. Sukintaka.(1992).Teori Bermain. Depdikbudjen. Proyek Pembinaan Tenaga Pendidikan.

Zainuddin, (2009). (Al-Bantany112.Blogspot.com/2009/11/Kumpulan-TeoriKerjasama.html). Diakses 20 April 2017 